\title{
Pallet depalletization method
}

\author{
Sposób depaletyzacji palet
}

During the process of making products, there is necessary to deliver pallets that are transported in a single composition or an alternating composition. In the second case, there is a need to use a depalletizer of wooden pallets which allow disjunction and proper orientation of pallets. KEYWORDS: depalletization, wooden pallets, post pallet

W procesie produkcji niezbędne jest dostarczanie palet. Są one transportowane ułożone jedna na drugiej lub w ułożeniu naprzemiennym. W drugim przypadku konieczne jest zastosowanie depaletyzatora palet drewnianych, który umożliwia rozdzielenie oraz odpowiednią orientację palet.

SŁOWA KLUCZOWE: depaletyzacja, drewniane palety, słupek palet

\section{Wprowadzenie}

W trakcie procesu wytwarzania produktów niezbędne jest dostarczanie palet. Są one dostarczane na dwa sposoby:

- ułożone prosto - w jednoznaczny oraz taki sam sposób (rys. 1),

- ułożone naprzemiennie, w słupek (rys. 2), aby zmniejszyć objętość przewożonych palet.

W celu zwiększenia liczby transportowanych palet układa się je w tzw. kanapkę. Jeden samochód ciężarowy z naczepą o standardowych wymiarach może przewieźć 700 sztuk palet ułożonych w słupek („kanapkę”) albo 532 palety w przypadku prostego ułożenia. Różnica wynosi więc 168 sztuk tylko pod-

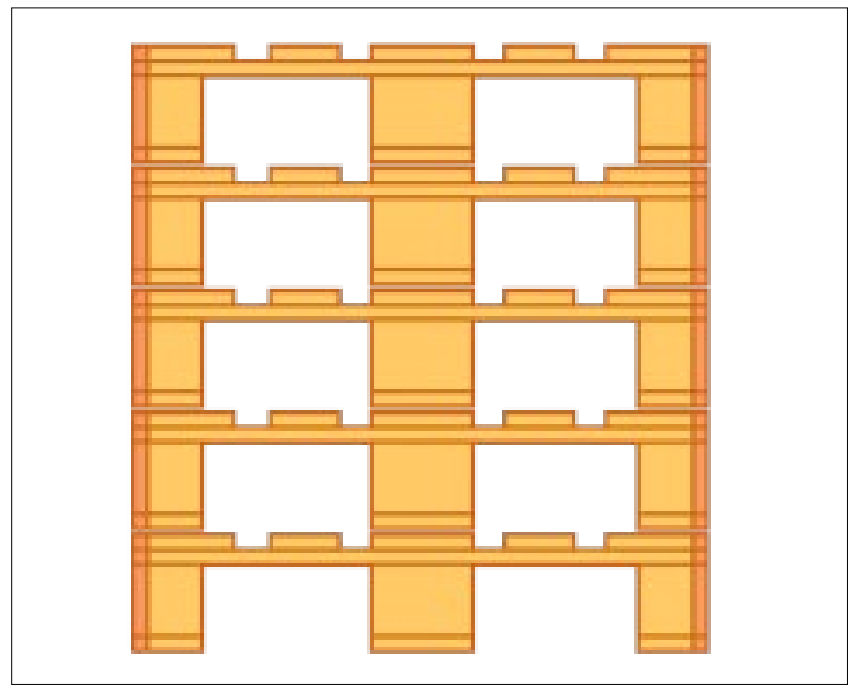

Fig. 1. Single composition of pallets Rys. 1. Proste ułożenie palet czas jednego transportu. Jednakże wadą układania naprzemiennego jest konieczność odwracania co drugiej palety przed procesem paletyzacji wytworzonych produktów.

Na rynku dostępne są urządzenia służące do odwracania co drugiej palety, ale są one bardzo duże i skomplikowane. Wykorzystuje się je w zakładach o dużej produkcji, natomiast w średnich firmach nie są stosowane ze względu na rozmiary oraz cenę.

Ponieważ praca przy przekładaniu palet jest dużym obciążeniem dla pracowników, średnie firmy są żywo zainteresowane tego typu urządzeniami. Stało się to inspiracją pracy dyplomowej inżynierskiej na Wydziale Mechatroniki Politechniki Warszawskiej, poświęconej koncepcji odwracania palet oraz modelowi 3D urządzenia.

\section{Koncepcja urządzenia do odwracania palet}

Słupek palet (rys. 3) jest dostarczany do maszyny za pomocą wózka widłowego. Palety zostają umieszczone na transporterze, a następnie są przenoszone do klatki rozdzielającej. Aby rozdzielić „kanapkę”, konieczne jest podniesienie słupka bez ostatnich dwóch palet.

Na podstawie przyjętej koncepcji działania zaprojektowano model 3D (rys. 4).

Słupek palet (1) (rys. 5) jest odstawiany na transporter rolkowy, w którym zamocowano płaskowniki (2) uniemożliwiające wypadnięcie elementów z transportera. Rolki (3) obracają się i przemieszczają

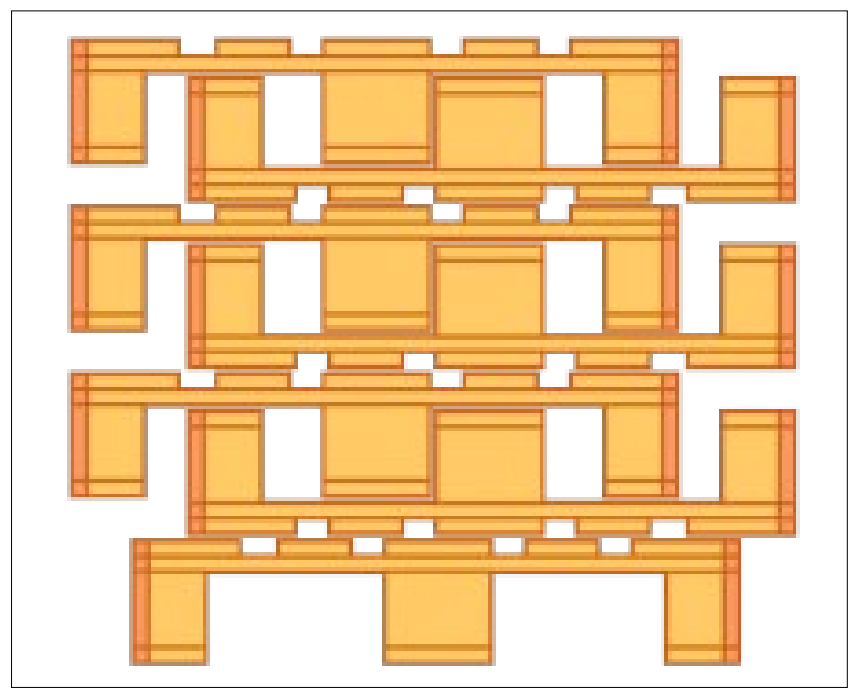

Fig. 2. Post pallets

Rys. 2. Słupek palet

\footnotetext{
* Inż. Kacper Bania, kacper.bania98@gmail.com - Wydział Mechatroniki, Politechnika Warszawska, Warszawa, Polska
} 


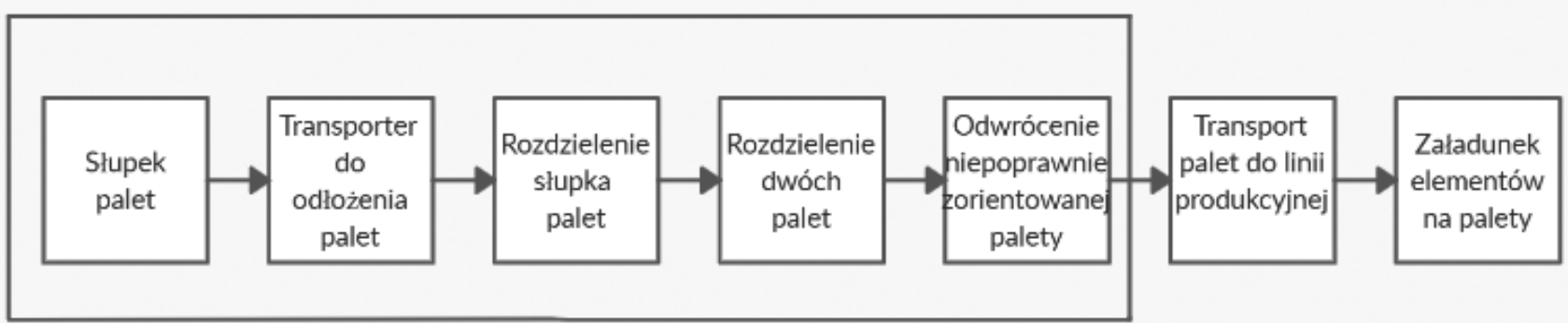

Przedmiot pracy

Fig. 3. Algorithm of disjunction process of post pallets

Rys. 3. Algorytm procesu rozdzielania słupka palet

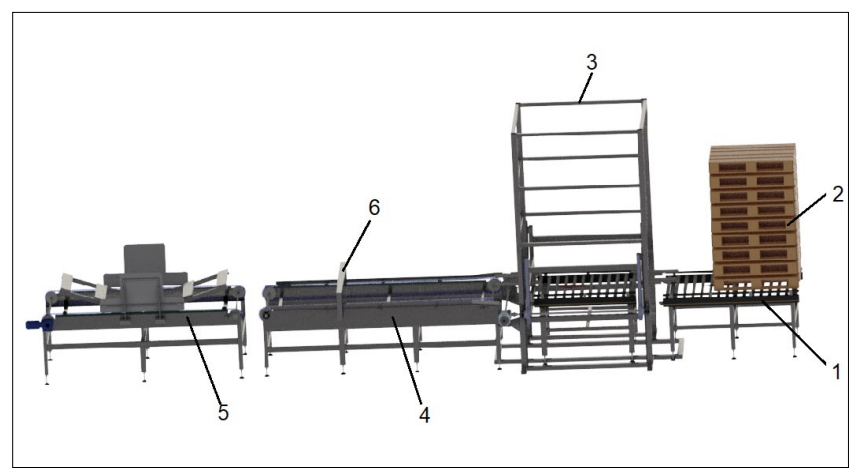

Fig. 4. The structure of mechanical system depalletizer of wooden euro pallets. 1 - roller conveyor, 2 - post pallets, 3 - post pallets separating cage, 4 - chain conveyor with drivers, 5 - chain conveyor with pallet reversing system, 6 - crossbar

Rys. 4. Struktura układu mechanicznego depaletyzatora palet drewnianych typu euro. 1 - transporter rolkowy, 2 - słupek palet, 3 - klatka rozdzielająca słupek palet, 4 - transporter łańcuchowy z zabierakami, 5 - transporter łańcuchowy z systemem odwracania palet, 6 - poprzeczka

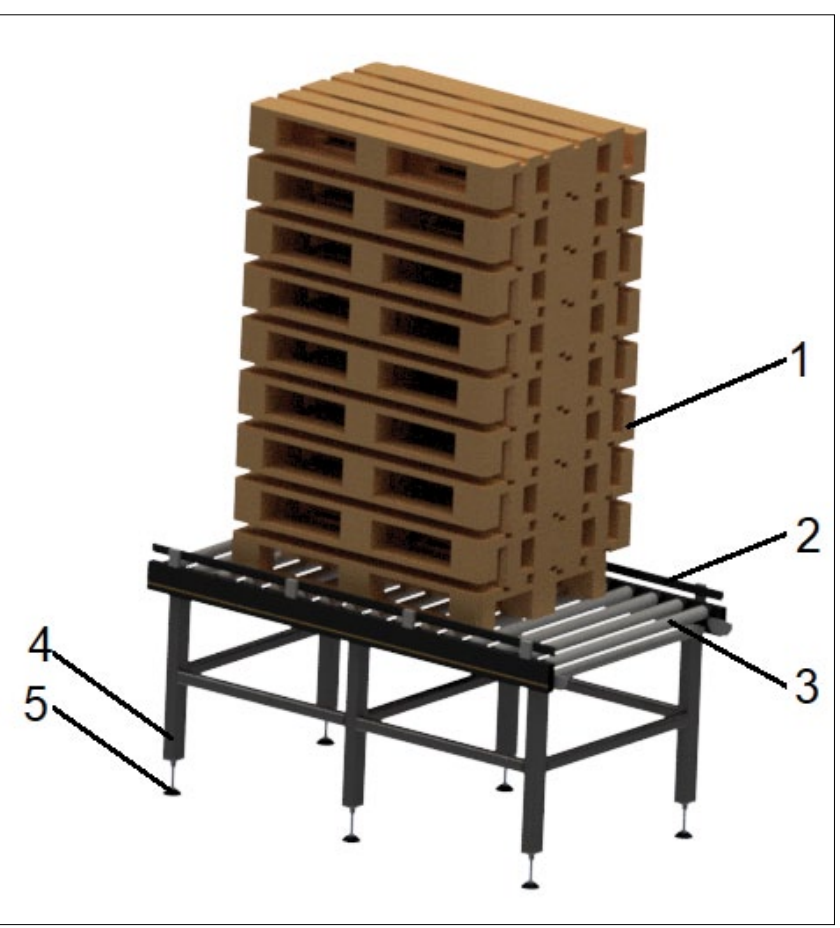

Fig. 5. Roller conveyor to postpone post pallets. 1 - post pallets, 2 - flat bar which protects against the post pallets falling, 3 - roller of conveyor roller, 4 - steel structural profile, 5 - height adjustable foot Rys. 5. Transporter rolkowy do odłożenia słupka palet. 1 - słupek palet, 2 - płaskownik, który zabezpiecza przez spadnięciem słupka palet, 3 - rolka transportera rolkowego, 4 - stalowy profil konstrukcyjny, 5 - stopka z możliwością regulacji wysokości

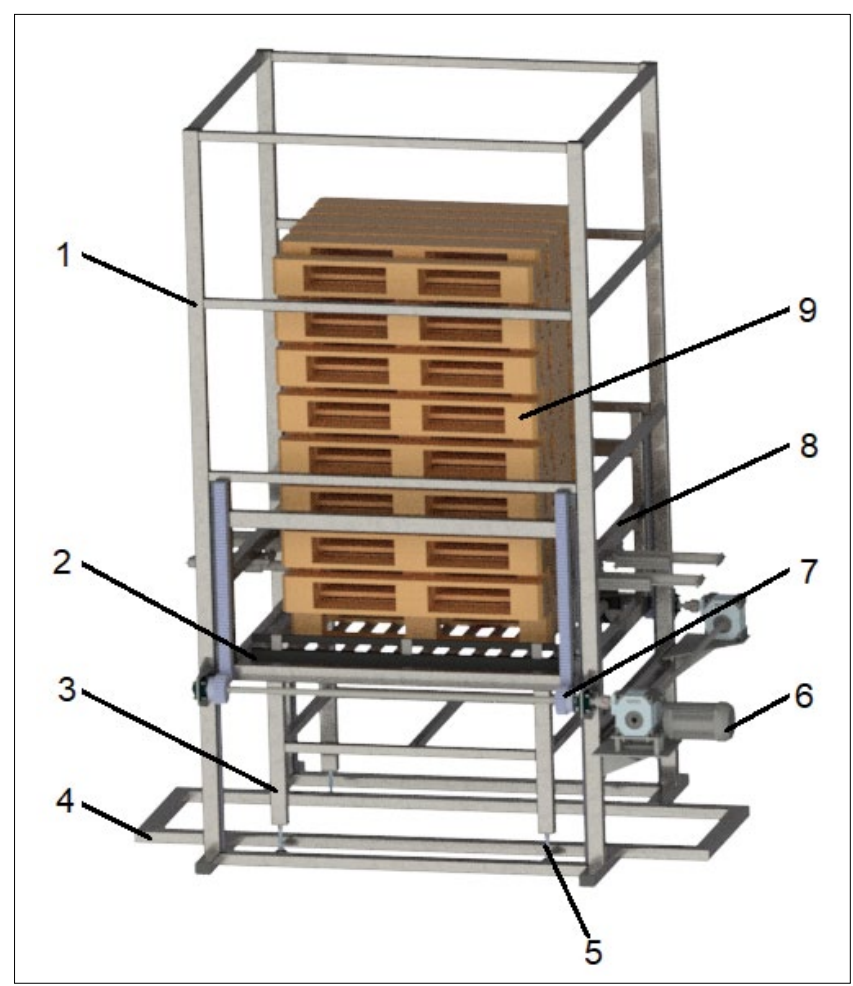

Fig. 6 . The dividing cage of post pallets. 1 - steel structural profile, 2 - roller conveyor, 3 - roller conveyor frame, 4 - steel structural profile, 5 - height-adjustable foot, 6 - drive unit, 7 - rack and pinion mechanism, 8 - reciprocating frame - returnable, 9 - post pallets Rys. 6. Klatka rozdzielająca słupek palet. 1 - stalowy profil konstrukcyjny, 2 - transporter rolkowy, 3 - rama transportera rolkowego, 4 - stalowy profil konstrukcyjny, 5 - stopka z regulacją wysokości, 6 - zespół napędowy, 7 - mechanizm zębatkowy, 8 - rama wykonująca ruch posuwisto-zwrotny, 9 - słupek palet

palety. Stalowe profile konstrukcyjne (4) zapewniają sztywność oraz stabilność całej konstrukcji. Wysokość transportera rolkowego jest regulowana stopką (5).

Słupek palet (9) (rys.6) jest przemieszczany za pomocą transportera rolkowego (2), który jest zamocowany na ramie (3) z możliwością regulacji wysokości stopek (5). Klatka jest wykonana z profili konstrukcyjnych (4). Ze względu na duże rozmiary gabarytowe klatki (wysoko umieszczony środek ciężkości) podstawa klatki jest znacznie szersza, co zapewnia stabilność całej konstrukcji. Profile konstrukcyjne (1) gwarantują sztywność. Rama (8) wykonuje ruch posuwisto-zwrotny w kierunku pionowym za pomocą zespołu napędowego (6) oraz mechanizmu zębatkowego (7). 


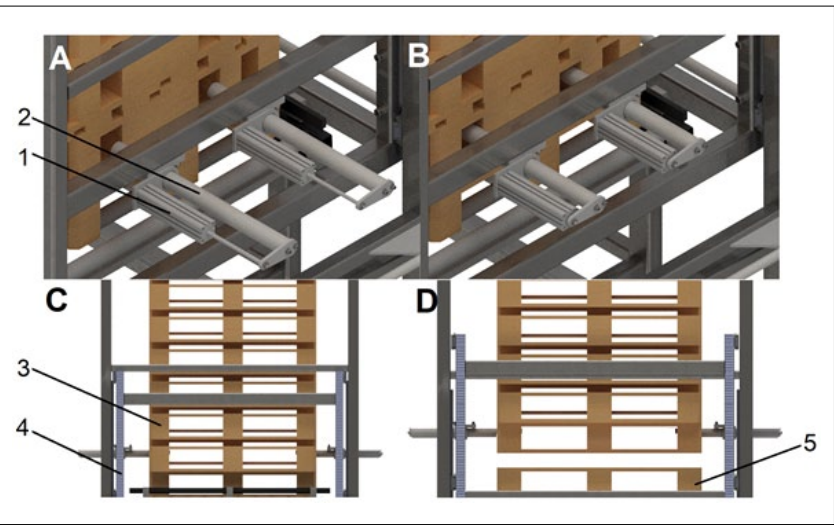

Fig. 7. Process of dividing post pallets. $A$ - initial position of the shaft coupled with the pneumatic actuator, $B$ - inserting the shafts, $C-$ in itial position of the post pallets, $D$ - lifting the post pallets. 1 - pneumatic cylinder, 2 - rod, 3 - post pallets, 4 - frame, 5 - last (bottom) pair of pallets

Rys. 7. Proces rozdzielania słupka palet. $A$ - pozycja początkowa wałka sprzęgniętego z siłownikiem pneumatycznym, $B$ - wsunięcie wałków, $C$ - początkowe położenie słupka palet, $D$ - podniesienie słupka palet. 1 - siłownik pneumatyczny, 2 - pręt, 3 - słupek palet, 4 - rama, 5 - ostatnia (dolna) para palet

Proces podnoszenia oraz rozdzielania słupka palet przedstawiono na rys. 7. Pręt (2) jest połączony z siłownikiem pneumatycznym (1), a następnie zostaje wsunięty w słupek palet (3). Rama (4), wykonując ruch posuwisto-wzdłużny $\mathrm{w}$ kierunku pionowym, podnosi słupek bez ostatniej (dolnej) pary palet (5).

Silnik trójfazowy (1) (rys. 8) napędza wał, na którym jest zamocowane koło zębate (2). Cały wał jest ułożyskowany w zespole łożyskowym (3). Transporter łańcuchowy jest zamocowany na ramie (5), której wysokość można regulować za pomocą stopki (4). Łańcuch ma zapewnione prowadzenie $\mathrm{w}$ prowadnicach łań-

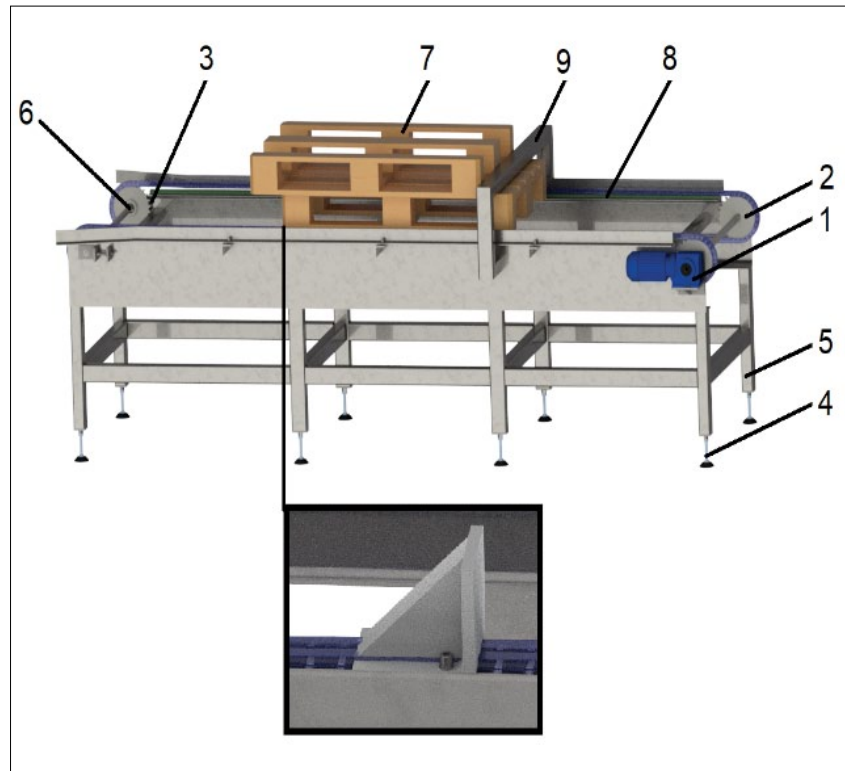

Fig. 8. Chain conveyor with lifters. 1 - three-phase motor, 2 - gear, 3 - bearing unit, 4 - foot with adjustable height, 5 - frame, 6 - sliding gear, 7 - pair of pallets, 8 - chain guide, 9 - crossbar

Rys. 8. Transporter łańcuchowy z zabierakami. 1 - silnik trójfazowy, 2 - koło zębate, 3 - zespół łożyskowy, 4 - stopka z możliwością regulacji wysokości, 5 - rama, 6 - koło zębate przesuwne, 7 - para palet 8 - prowadnica łańcuchowa, 9 - poprzeczka

cuchowych (8). Poprzeczka (9), która rozdziela parę palet (7), jest zamocowana w sposób trwały do ramy transportera łańcuchowego. Koło zębate przesuwne (6) umożliwia napinanie łańcucha.

Proces rozdzielania pary palet przedstawiono na rys. 9. Para palet jest przesuwana za pomoca transportera łańcuchowego (4). Poprzeczka (1) zatrzymuje górną paletę (2), a dolna paleta (3) jest transportowana pod poprzeczką.

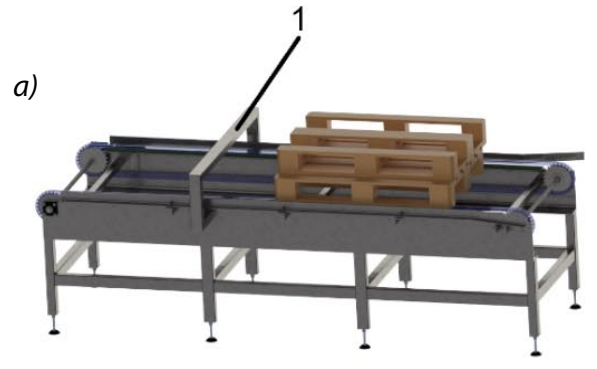

c)

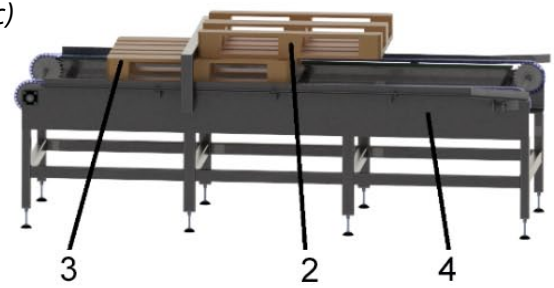

b)

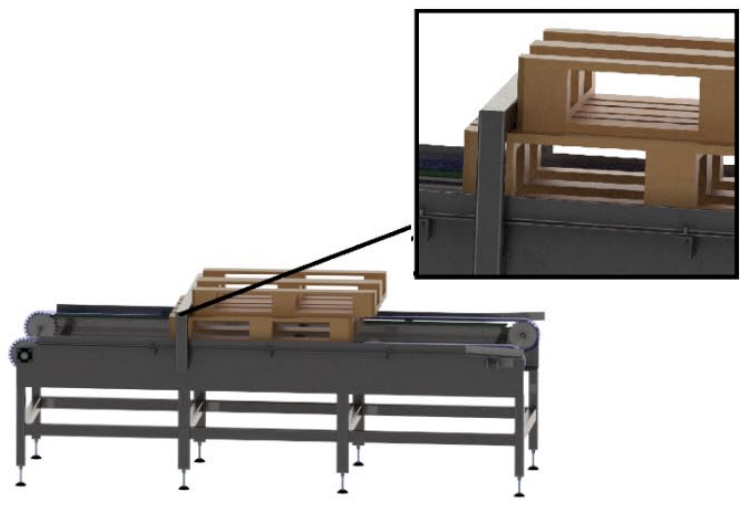

d)

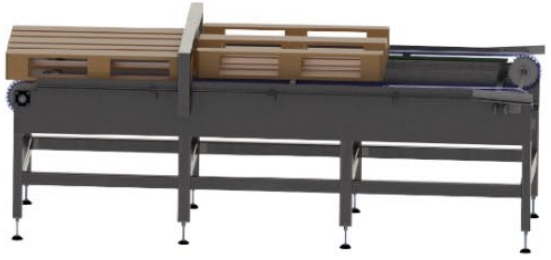

Fig. 9. Process of dividing pair pallets. $A$ - transporting a pair of pallets, $B$ - initiating the process of separating two pallets, $C$ - the final phase of the process of separating the pallets, $D$ - the end of the process of separating the pallets. 1 - crossbar, 2 - upper pallet, 3 - lower pallet, 4 - chain conveyor

Rys. 9. Proces rozdzielania dwóch palet. $A$ - transportowanie pary palet, $B$ - inicjacja procesu rozdzielania dwóch palet, $C$ - końcowa faza procesu rozdzielania palet, $D$ - koniec procesu rozdzielania palet. 1 - poprzeczka, 2 - górna paleta, 3 - dolna paleta, 4 - transporter łańcuchowy 


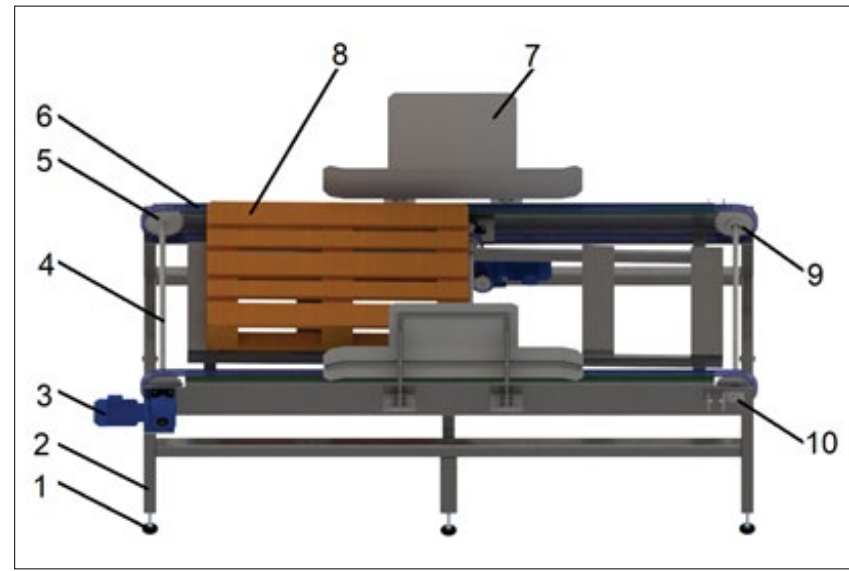

Fig. 10. View of chain conveyor with deflecting system. 1 - foot with adjustable height, 2 - steel structural profile, 3 - three-phase motor, 4 - drive shaft, 5 - non-moving gear wheel, 6 - chain guide, 7 - plate preventing the pallet from falling out, 8 - reversible pallet, 9 - sliding gear wheel, 10 - chain tensioning mechanism

Rys. 10. Widok transportera łańcuchowego z systemem odwracania palet z boku. 1 - stopka z możliwością regulacji wysokości, 2 - stalowy profil konstrukcyjny, 3 - silnik trójfazowy, 4 - wał napędowy, 5 - koło zębate nieprzesuwne, 6 - prowadnica łańcuchowa, 7 - blacha uniemożliwiająca wypadnięcie palety, 8 - odwracana paleta 9 - koło zębate przesuwne, 10 - mechanizm umożliwiający napinanie łańcucha

Stalowe profile konstrukcyjne (2) (rys. 10) gwarantują stabilność oraz sztywność transportera łańcuchowego, którego wysokość można regulować za pomocą stopki (1). Silnik trójfazowy (3) napędza wał (4) sprzęgnięty z nieprzesuwnym kołem zębatym (5), które wprawia w ruch łańcuch mający prowadzenie w prowadnicach łańcuchowych (6). Mechanizm (10) umożliwia napinanie łańcucha. Blacha (7) uniemożliwia odwracanej palecie (8) wypadnięcie z transportera łańcuchowego.

Niepoprawnie zorientowana paleta (1) (rys.11) przemieszcza się po transporterze łańcuchowym (3). System odwracania palet oraz rama (2) zmieniają położenie palety.

\section{Podsumowanie}

Trudnościami, które się pojawiły podczas opracowywania konstrukcji mechanicznej depaletyzatora palet drewnianych typu euro, były opracowanie metody rozdzielania słupka palet i odwracanie niepoprawnie zorientowanej palety.

Ze względu na wysoko umieszczony środek ciężkości konieczne było zapewnienie stabilności oraz sztywności całej ramy wykonanej ze stalowych profili konstrukcyjnych. Dodatkowym wyzwaniem było poprawne zaprojektowanie zespołu wsuwającego/ /wysuwającego pręty, aby nie doszło do ich zakleszczenia. Aby uniknąć tego problemu, zastosowano tuleje wykonane z brązu.

Koniecznym wymaganiem było jak najszybsze dokonanie procesu odwrócenia niepoprawnie zorientowanej palety. Fakt ten uniemożliwiał zastosowanie innych rozwiązań konstrukcyjnych; jedynie wykorzystana metoda spełnia wymagane założenia oraz dodatkowo cechuje się relatywnie niskim kosztem produkcji, a także niezawodnością działania.

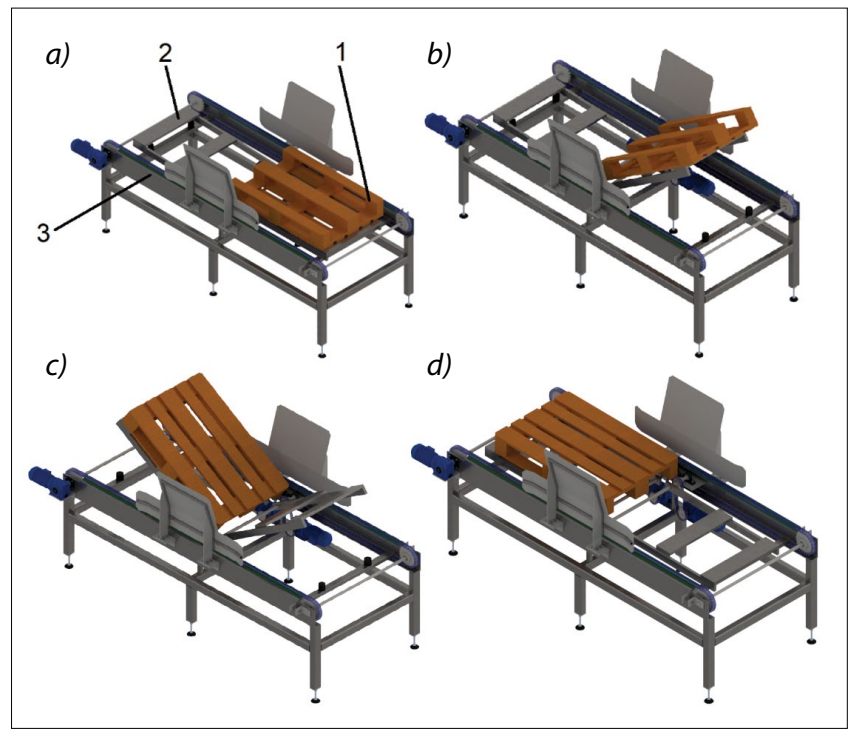

Fig. 11. Process of deflecting improperly oriented pallet. $A$ - initiation of the process of turning an incorrectly oriented pallet, $B$ - lifting the pallet on one arm, $C$ - contact of the pallet with the other arm, $D$ lowering the correctly oriented pallet. 1 - incorrectly oriented pallet, 2 - frame, 3 - chain conveyor

Rys. 11. Proces odwracania niepoprawnie zorientowanej palety. $A$ - inicjacja procesu odwracania niepoprawnie zorientowanej palety, $B$ - podnoszenie palety na jednym ramieniu, $C$ - kontakt palety $z$ drugim ramieniem, $D$ - opuszczenie poprawnie zorientowanej palety. 1 - niepoprawnie zorientowana paleta, 2 - rama, 3 - transporter łańcuchowy

Dobrym rozwiązaniem ułatwiającym obsługe maszyny jest zastosowanie obrotnicy zamiast transportera rolkowego, na który odkłada się słupek palet. Wtedy operator wózka widłowego nie musiałby odkładać słupka palet w określonej pozycji (dłuższy bok równolegle do transportera). Błędne odstawienie słupka palet byłoby korygowane przez obrotnicę. Ponadto w przyszłości należałoby zastosować osłony na ruchome elementy, a także kratki bezpieczeństwa oddzielające moduł rozdzielający słupek palet oraz moduł odwracający niepoprawnie zorientowane palety, co przyczyniłoby się do wzrostu bezpieczeństwa podczas użytkowania maszyny.

Podsumowując wykonane prace: zaprojektowane urządzenie służące do depaletyzacji palet drewnianych typu euro jest nieodłączną częścią linii produkcyjnych, do których trzeba dostarczać poprawnie zorientowane palety. Tansportowanie palet do różnych części linii produkcyjnych jest wymagane ze względu na rosnącą liczbę wytwarzanych produktów, które muszą zostać umieszczone na paletach do dalszego transportu.

\section{LITERATURA}

[1] https://www.ventech.pl/suszarnie-do-palet/ (dostęp: 14.10.2020 r.).

[2] Linia rozsztaplowania weryfikacji (kontroli) oraz sztaplowania palet, firma PENNY Dobroszyce, https://www.penny.pl/ (dostęp: 14.10.2020 r.).

[3] Jereczek J., Budniak Z., Karaczun A. „Zastosowanie technik CAD/CAE do projektowania i analiz nożycowych podnośników samochodowych". Warszawa: PWN, 2014.

[4] https://europasystems.pl/product-pol-36-Przenosnik-tasmowy.html (dostęp: 16.10.2020 r.).

[5] Kurmaz L.W. „Podstawy konstrukcji maszyn - Projektowanie". Warszawa: PWN, 1999. 